\title{
Wild edible plants in four Agni tribes of Central-east and Northeast of Côte d'Ivoire: a comparative study
}

\author{
DJAH FRANÇOIS MALAN ${ }^{1,2, \vartheta}$, AMANI LÉOPOLD LITTA ${ }^{1}$, MÉNÉKÉ DISTEL KOUGBO ${ }^{1}$, AMADOU \\ LAMINE DIOP ${ }^{1}$, KOUASSI GÉRARD KOUASSI ${ }^{1}$ \\ ${ }^{1}$ Université Nangui Abrogoua, U.F.R. des Sciences de la Nature. BP 02 BP 801, Abidjan 02, République de Côte d’Ivoire \\ vemail: malandf@gmail.com \\ ${ }^{2}$ Institut Botanique Aké-Assi d'Andokoi. BP 08 BP 172, Côte d'Ivoire
}

Manuscript received: 29 June 2020. Revision accepted: 28 September 2020.

\begin{abstract}
Malan DF, Litta AL, Kougbo MD, Diop AL, Kouassi KG. 2020. Wild edible plants in four Agni tribes of Central-east and Northeast of Côte d'Ivoire: a comparative study. Biodiversitas 21: 4896-4902. An ethnobotany survey was carried out in twelve villages of the four Agni tribes from the Center-east to Northeast of the Côte d'Ivoire, in order to assess the evolution of the knowledge and know-how of these peoples concerning wild edible plants. Frequency of citations and the Smith index of each of edible plants were obtained with data from the survey of 571 informants ( 279 men and 292 women). Factorial analysis of the correspondences was also performed in order to reveal the similarities between the different tribes. In total, 77 plant species (36 families and 67 genera) were cited as consumed by humans. The most used parts are the fruits (65.38\%), and leaves (24.36\%). Analysis of the similarities shows that only $18.82 \%$ of these species are common to the four tribes. In addition, knowledge related to wild edible plants is gradually degrading, for several reasons, including obsolescence of use and the unavailability of plants due to environmental degradation. Thus, the valuation and protection of these resources would be beneficial to populations.
\end{abstract}

Keywords: Agni tribes, Côte d'Ivoire, ethnobotanical study, wild edible plants

\section{INTRODUCTION}

People in Africa have a long tradition of using wild edible plants (Dally et al. 2008). They use them as a condiment or dietary supplement in the preparation of their various typical dishes (Dally et al. 2008; Bédiakon et al. 2018). In order to cover their food needs, rural populations resort to subsistence farming, which they supplement with edible wild species (Bédiakon et al. 2018; Batawila et al. 2007). These plants contain, by their compositions, a source of appreciable supplements of calories, vitamins, fibers, mineral salts, and proteins in the diet (Batawila et al. 2007; Ouattara et al. 2016a; Ojelel et al. 2019). In Côte d'Ivoire, these plants are mainly used in rural areas. However, the degradation of the Ivorian forest, which has gone from 16 million ha to less than 2.5 million ha in fifty years (Traoré 2018), poses various ecological problems to which is added the scarcity of wild edible plants (Kouamé et al. 2008). As a result, some plants tend to fall into disuse in many rural households (Dally et al. 2008).

The vast majority of studies conducted in Côte d'Ivoire on the subject have revealed the scarcity of several plant species, and the loss of traditional knowledge and skills related to these plants (Ouattara et al. 2016a). Given that the usual value of a plant is strongly correlated with its availability (Lucena et al. 2007), these plants deserve special attention and an appreciation of the knowledge and know-how of the peoples in this area (Djaha and Gnahoua 2014). This attention could allow them to be taken into account in the development of new action strategies against food insecurity (Lugo-Morin 2020). In the central-east and northeast of Côte d'Ivoire, straddling the semi-deciduous forest and the preforest sector of the Guinean domain, are four Agni tribes, forming an intermediate linguistic limit between the Djimini, Koulango peoples, more in the North and the great Agni Kingdoms (Djuablin and Indenié), further to the South. At the present, the botanical knowledge and know-how of these peoples have been very little documented.

However, it is known that any use of a plant is linked to the socio-cultural behavior of communities (Yetein et al. 2013). Therefore, this study aimed to assess the evolution of knowledge and practices concerning wild edible plants (WEP) within each of these tribes as well as the level of knowledge sharing between these Agni subgroups. Specifically, it involved (i) assessing the level of intercultural knowledge between the tribes; (ii) determining the level of knowledge sharing on WEP between tribes.

\section{MATERIALS AND METHODS}

\section{Study areas}

The study was conducted in three Departments (Daoukro, Koun-fao, and Sandegué) from the central-east to the northeast of Côte d'Ivoire (Figure 1), from March 2016 to September 2019. This area includes four subprefectures and 12 villages including Ettrokro, Katimansou, and Zanzansou for the Agni-Abè (sub-prefecture of Ettrokro), Sanguehi, Kamélé, and Kouakoukankro for the Agni-Barabo (sub-prefecture of Sandégué), Senandé, Yakassé-bini, and Missoumihian 1 for the Agni-Bini 
(Kouassi-Datékro sub-prefecture,) and Kokomian, Bossignanienkro and Sogoyaokro for the Agni-Bona (Kokomian sub-prefecture). The study area is between two main types of vegetation in the Guinean area: the mesophilic sector and the preforest sector. The mesophilic sector (Daoukro and Koun-fao) is characterized by a semideciduous forest type with a subequatorial climate (Kouassi et al. 2010). The preforest sector is characterized by the forest-savannah transition with a clear dominance of savannah formations, and a Sudanese climate of the humid tropical type (Ouattara et al. 2016a). The main activity of these populations is agriculture.

\section{Ethnobotanical survey}

The term "wild edible plant" in this context refers to plants that settle and grow without human intervention in a field. All spontaneous plant species or products of wild plant species consumed raw, after cooking or other processing by humans as food or drink are concerned. The ethnobotany survey was carried out in two stages using an interview guide.

The first stage consisted of a semi-structured interview following the free lists approach (Quinlan 2005) during a random "door-to-door" in households in each village. The interviews focused on the spontaneous plants consumed by the populations, their local names, the parts consumed as well as the modes of consumption. It involved 571 informants distributed as follows: 174 Agni-Abè (71 women and 103 men), 182 Agni-Barabo (92 women and 90 men), 118 Agni-Bini (68 women and 50 men), and finally
96 Agni-Bona (61 women and 35 men). For the second stage, walks in the surrounding "bushes" were organized with informants. At the end of this stage, the previous lists collected during the first stage were completed and herbarium vouchers were collected for botanical identification at Nangui Abrogoua University. The scientific names were updated using the African Plants Database (Version 3.4.0), consulted on 24/04/2019.

\section{Data analysis}

To understand the level of knowledge, preference, and cultural importance of plants to people, two consensus indices were used: the frequency of citation $(\mathrm{Fc})$ (Equation 1) and the Smith's index (Equation 2). The first index assesses the credibility of the information received and the level of knowledge of the communities (Schrauf and Sanchez 2008). The second also assesses the importance of the listed species, but especially the preference of respondents in the community (Borgatti 1996).

$$
F c=\frac{N i}{N} \times 100
$$

Where; $F c$ : frequency of quotation, $N i$ : number of times where the item (plant) is mentioned, and $N$, the total number of informants. Species, with an Fc between $50 \%$ and $100 \%$ are the best known, those moderately known have an $\mathrm{Fc}$ between $25 \%$ and $50 \%$, those whose $\mathrm{Fc}$ is between $00 \%$ and $25 \%$ are the little known species (Kouamé et al. 2008).

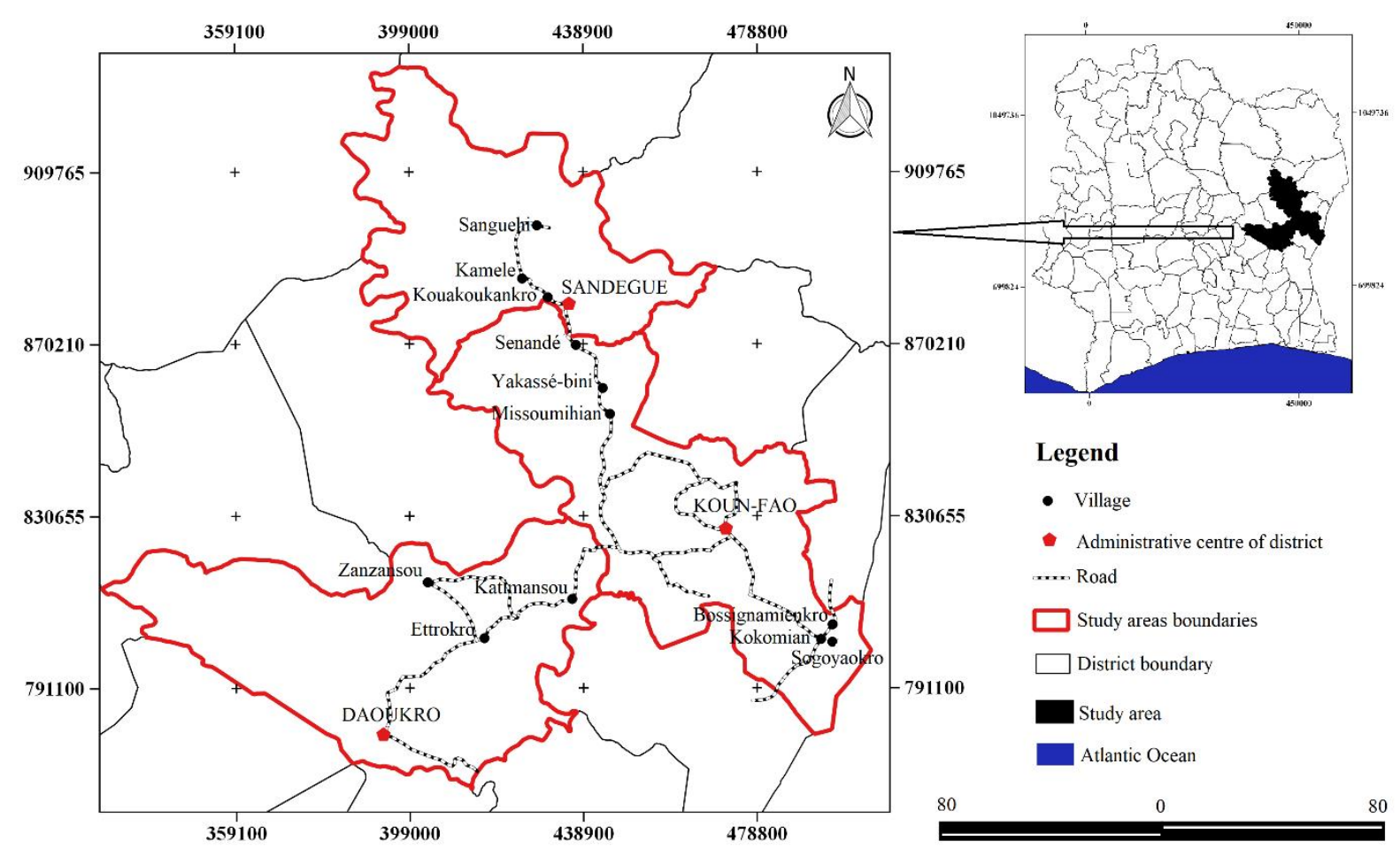

Figure 1. Location of the study area: Departments of Daoukro, Koun-fao and Sandégué, Côte d'Ivoire 


$$
S a=\frac{\sum_{i=1}^{N} \frac{\mathbb{L}_{i}-\mathbb{E}_{n+1}}{\mathbb{L}_{i}}}{N}
$$

Where; $S a$ is the importance of a citation, $L i$ the length of a citation list, and $R a$ the rank of a citation in the list, $N$ the number of free lists (number of respondents). A large value of this index (close to 1) indicates that the item is preferred and important for the respondents (Sutrop 2001).

\section{Statistical data analysis}

In addition, a correspondence analysis (FCA) coupled to a hierarchical cluster analysis was performed in order to show the level of knowledge sharing between tribes. The principle of this method is to study the connection between two sets of modalities that constitute the rows and columns of a contingency table (Orsay 1979). This analysis was carried out with the frequency of citation data of plants by tribe, using the R software (version 3.6.1).

\section{RESULTS AND DISCUSSION}

\section{Diversity of wild edible plants species}

Sixty-seven WEP species, distributed in 67 genera and 36 families, were collected. The most represented families included Malvaceae (10 species), Fabaceae (6 species), Apocynaceae, and Sapindaceae (5 species each). They were composed of 51 trees and shrubs, 16 herbaceous plants and 10 lianas.

\section{Parts and mode of consumption}

The parts consumed were the leaves, the flower, the fruits, the seeds, and the fermented sap (Figure 2). Overall, fruits $(65.38 \%)$ and leaves $(24.36 \%)$ were the most used. However, the level of organ consumption differed from one tribe to another: the Agni-Barabo had the highest fruit consumption rate while the Agni-Bona preferred the leaves. Fruits such as those of Uvaria chamae P. Beauv. and $U$. sofa Scott-Elliot (Figure 3) are sought after for their sweet and flavored pulps. Beverages made from fermented palm sap were not consumed by Agni-Barabo and Agni-Bini (Figure 4). Four consumption modes (snack, sauce, porridge, drink) were identified in the study area. In general, the most used mode of consumption is snacks $(65 \%)$. However, the proportion of consumption patterns varies according to the tribes. The proportion of sauce is higher among Agni-Abè and the proportion of snacks is higher among Agni-Barabo.

\section{Level of knowledge}

The specific richness of WEP varied from one tribe to another, with, in descending order, the Agni-Barabo (50 plants), the Agni-Abè (43 plants), the Agni-Bini (42 plants), and the Agni-Bona (32 plants). Concerning individual knowledge, Agni-Bini respondents come out on top with 9.05 plants on average per free list. They were followed by Agni-Barabo with 8.17 plants per list, AgniAbè with 7.79 plants per list, and Agni-Bona with 3.66 per list (Figure 4).

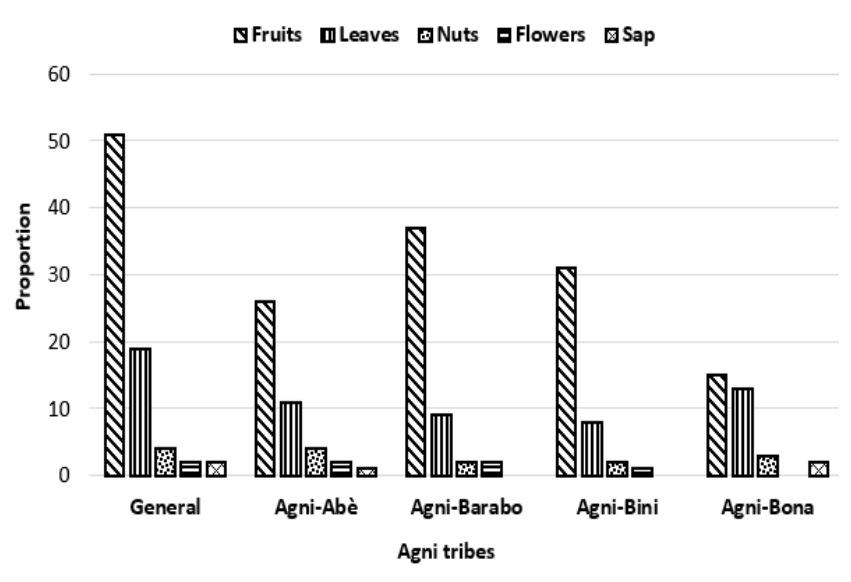

Figure 2. Proportion of wild edible plants parts consumed by Agni tribes, Côte d'Ivoire

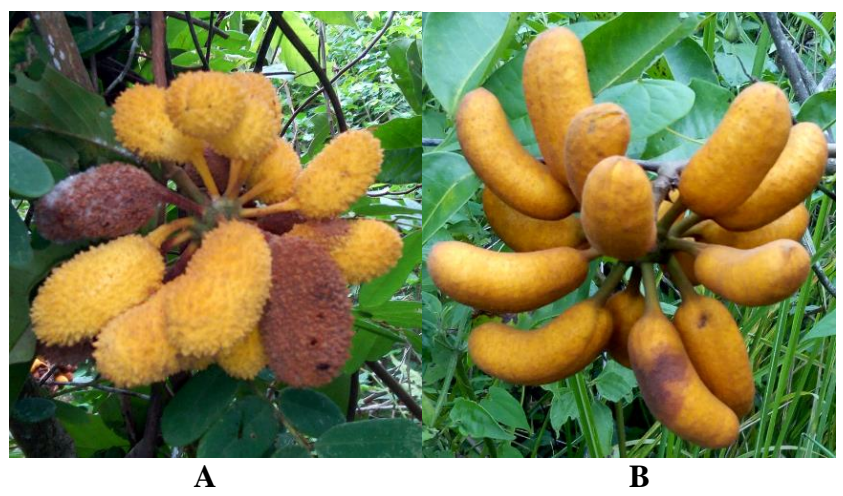

Figure 3. Fruits of two species consumed by the four Agni tribes, Côte d'Ivoire: A. Uvaria sofa Scott-Elliot, B. Uvaria chamae P. Beauv. (Photographs by Litta A.L.)

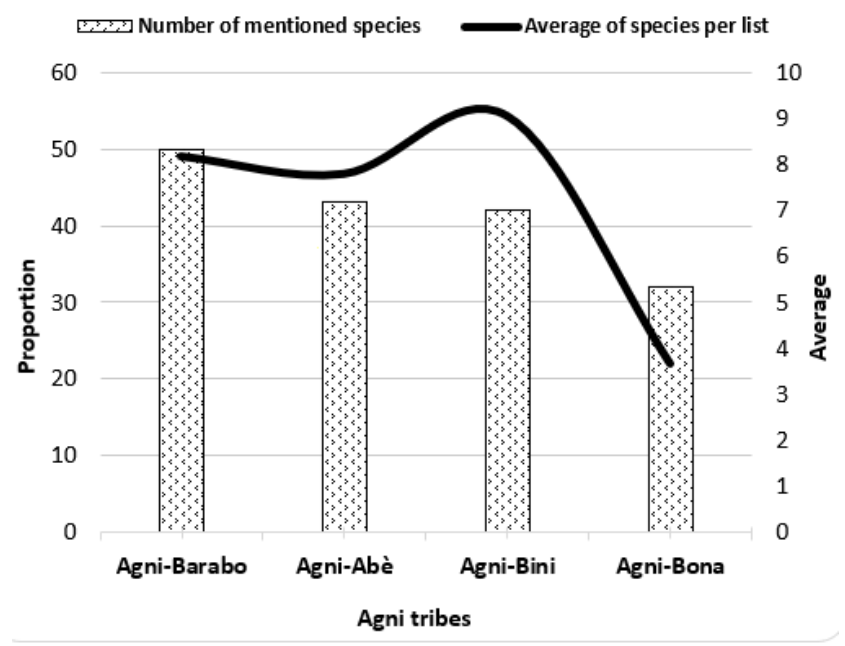

Figure 4. Number of wild edible plants cited and average of plants per free list of the four Agni tribes, Côte d'Ivoire 
Out of the seventy-seven edible species, only seven $(9.1 \%)$ species have a frequency of citation greater than $50 \%$. This number varies from one tribe to another. Thus, the Agni-Bini register four plants in this register, the AgniAbè and the Agni-Barabo, three plants, and finally a single plant in the Agni-Bona (Table 1). These seven well-known plants included Adansonia digitata L. $\left(\mathrm{Fc}_{\mathrm{Agni}-\mathrm{Barabo}}=57 \%\right)$. Ceiba pentandra (L.) Gaertn. $\left(\mathrm{Fc}_{\mathrm{Agni}-\mathrm{Abè}}=67 \%, \mathrm{Fc}_{\mathrm{Agni}-}\right.$ Barabo $\left.=79 \%, \mathrm{Fc}_{\mathrm{Agni}-\mathrm{Bini}}=54 \%\right)$, Cissus populnea Guill. $\&$ Perr. $\left(\mathrm{Fc}_{\mathrm{Agni}-\mathrm{Bini}}=54 \%\right)$, Landolphia dulcis (Sabine ex G.Don.) Pichon $\left(\mathrm{Fc}_{\mathrm{Agni}}\right.$-Abè $\left.=64 \%\right)$, Landolphia heudelotii A. DC. $\left(\mathrm{Fc}_{\mathrm{Agni}-\mathrm{Abè}}=56 \%, \mathrm{Fc}_{\mathrm{Agni} \text {-Barabo }}=63 \%, \mathrm{Fc}_{\mathrm{Agni}-\mathrm{Bini}}=\right.$ $61 \%)$, Solanum indicum L. $\left(\mathrm{Fc}_{\mathrm{Agni}-\mathrm{Bona}}=51 \%\right)$, et Spondias mombin L. $\left(\mathrm{Fc}_{\mathrm{Agni}-\mathrm{Bini}}=50 \%\right)$.

In contrast to the plants well known and important for these tribes, 16 of the plants cited by the Agni-Bona (i.e. $50 \%), 16$ of those cited by the Agni-Abè (37.21\%), 15 of those cited by the Agni-Barabo (30\%) and five (11\%) of those cited by the Agni-Bini were very little known $(\mathrm{Fq}<5 \%)$. These included, for example, Musanga cecropioides R.Br., Thaumatococcus daniellii (Benn.) Benth. (AgniAbè), Ricinodendron heudelotii (Bail.) Heckel (AgniBarabo), Pancovia sessiliflora Hutch. \& Dalziel (AgniBini), and Pentadesma butyracea L. (Agni-Bona).

\section{Distribution of species according to the four Agni tribes}

The correspondence analysis (Figure 5) coupled to the hierarchical cluster analysis (Figure 6) suggested three categories according to the frequency of citation. The first group (G1) included the plants cited by the Agni-Abè. The second group (G2) is formed by the plants mentioned by the Agni-Bona and the third group (G3) included plants cited by both the Agni-Bini and Agni-Barabo. It should be noted that this association is very significant $\left(\mathrm{Khi}^{2}=\right.$ 3056.791; p-value $=0$ ).

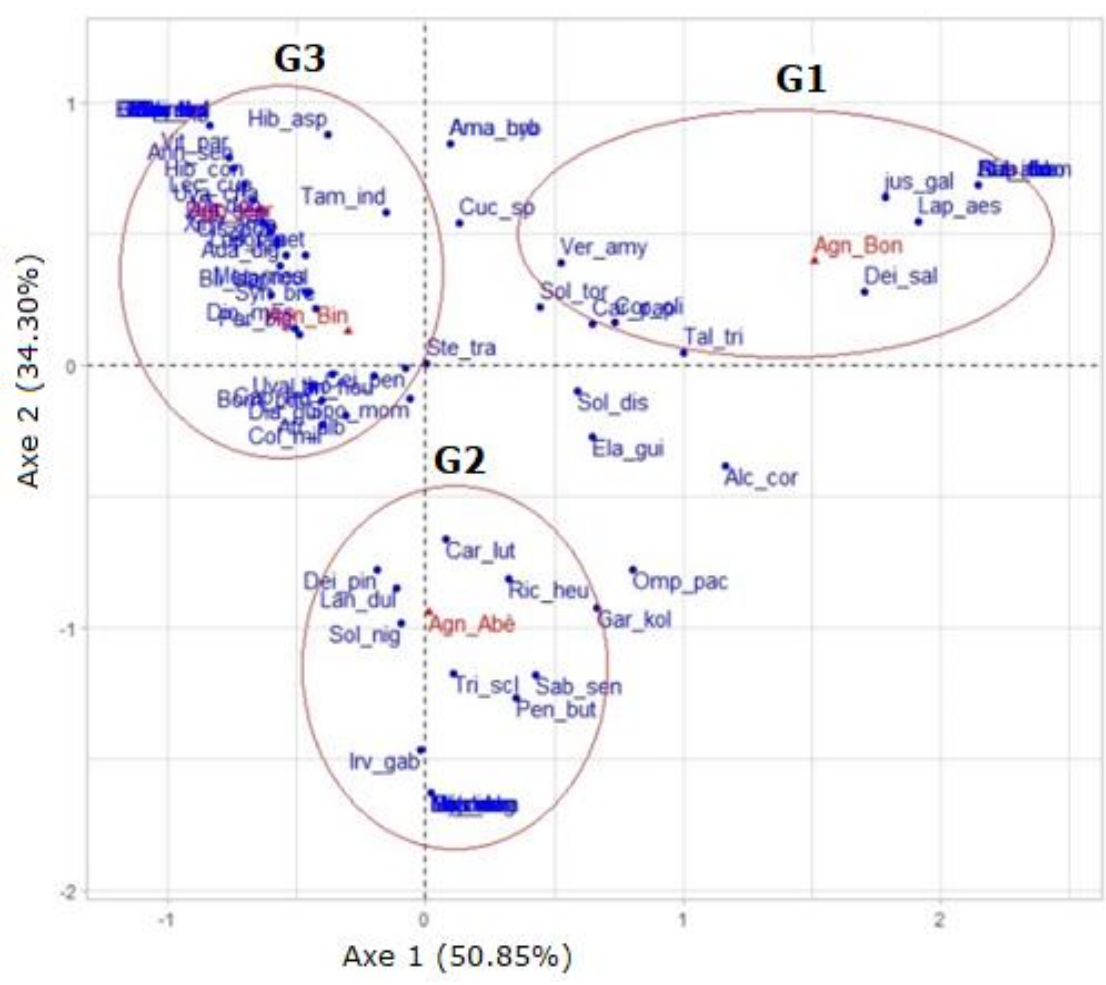

Figure 5. Distribution of wild edible plants by Agni tribes according to the first axis of the FCA

Table 1. Level of knowledge and cultural importance of wild edible plants of four Agni tribes, Côte d'Ivoire

\begin{tabular}{|c|c|c|c|c|c|c|c|c|c|c|}
\hline \multirow{2}{*}{ Species } & \multirow{2}{*}{ Family } & \multicolumn{2}{|c|}{ Agni-Abè } & \multicolumn{2}{|c|}{ Agni-Barabo } & \multicolumn{2}{|c|}{ Agni-Bini } & \multicolumn{2}{|c|}{ Agni-Bona } & \multirow{2}{*}{ Organ } \\
\hline & & Fc & $\mathbf{S a}$ & Fc & Sa & Fc & $\mathbf{S a}$ & Fe & Sa & \\
\hline Adansonia digitata $\mathrm{L}$. & Malvaceae & 12 & 0.04 & 57 & 0.18 & 42 & 0.36 & 1.1 & 0.01 & Leaves \\
\hline Aframomum alboviolaceum (Ridl,) K, Schum & Zingiberaceae & 11 & 0.06 & 8.2 & 0.05 & 15 & 0.03 & 1.1 & 0.01 & Fruits \\
\hline Afzelia africana Pers. & Fabaceae & - & - & - & - & - & - & 1.1 & 0 & Leaves \\
\hline Alchornea cordifolia (Schumach. \&Thonn.) Müll. Arg & Euphorbiaceae & 1.8 & 0 & - & - & - & - & 2.1 & 0.01 & Leaves \\
\hline Amaranthus hybridus L. & Amaranthaceae & - & - & 2.2 & 0 & - & - & 1.1 & 0.01 & Leaves \\
\hline Annona senegalensis Pers. & Annonaceae & - & - & 17 & 0.1 & 5.1 & 0.02 & - & - & Fruits \\
\hline Blighia welwitschii (Hiern) Radlk. & Sapindaceae & - & - & 1.1 & 0.01 & - & - & - & - & Fruits \\
\hline Bombax buonopozenseP.Beauv & Malvaceae & 9.5 & 0.02 & 12 & 0.05 & 10 & 0.06 & - & - & Flower \\
\hline Bombax costatum Pellegr. \& Vuillet & Malvaceae & - & - & 17 & 0.09 & - & - & - & - & Leaves \\
\hline
\end{tabular}




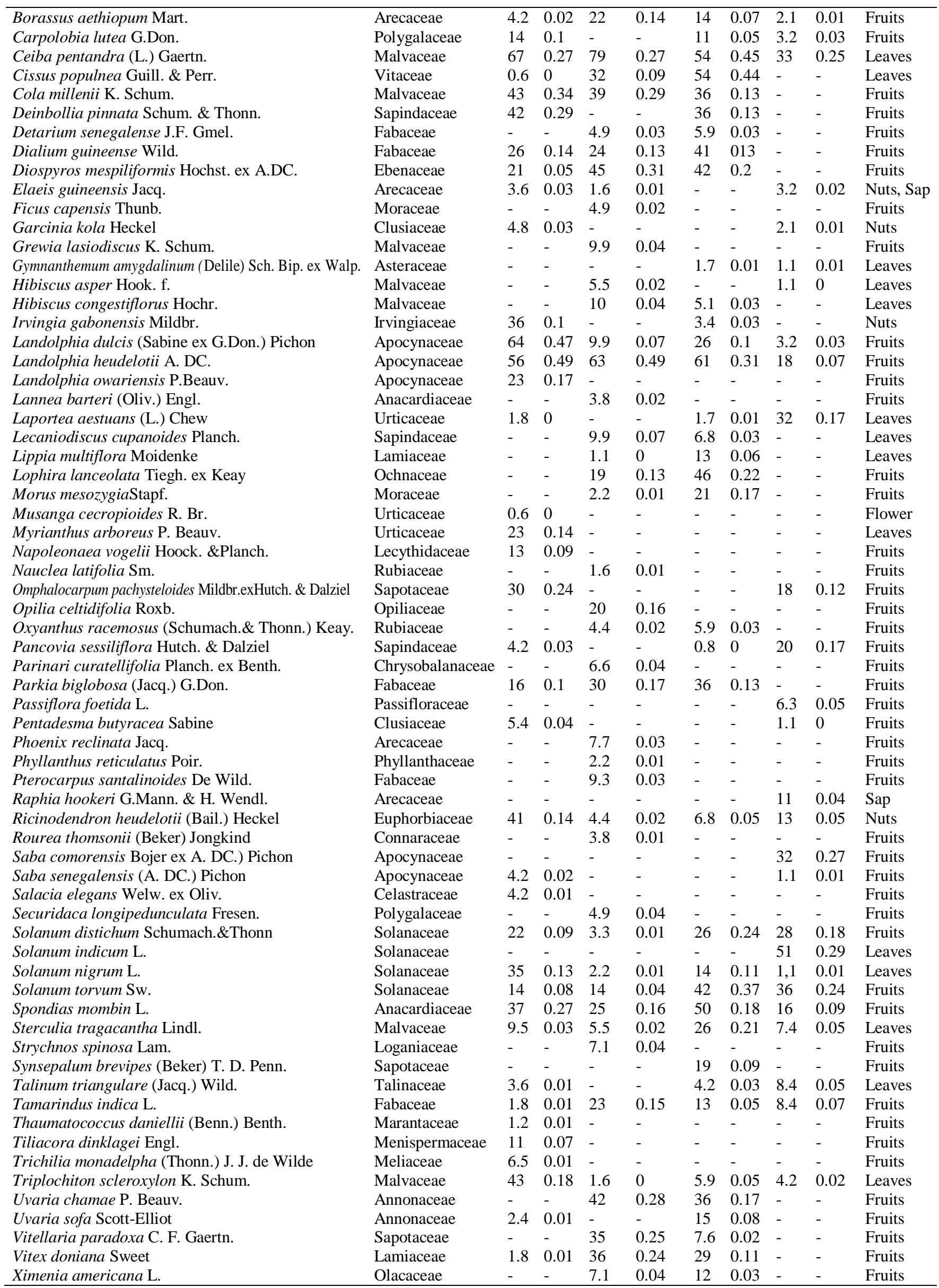




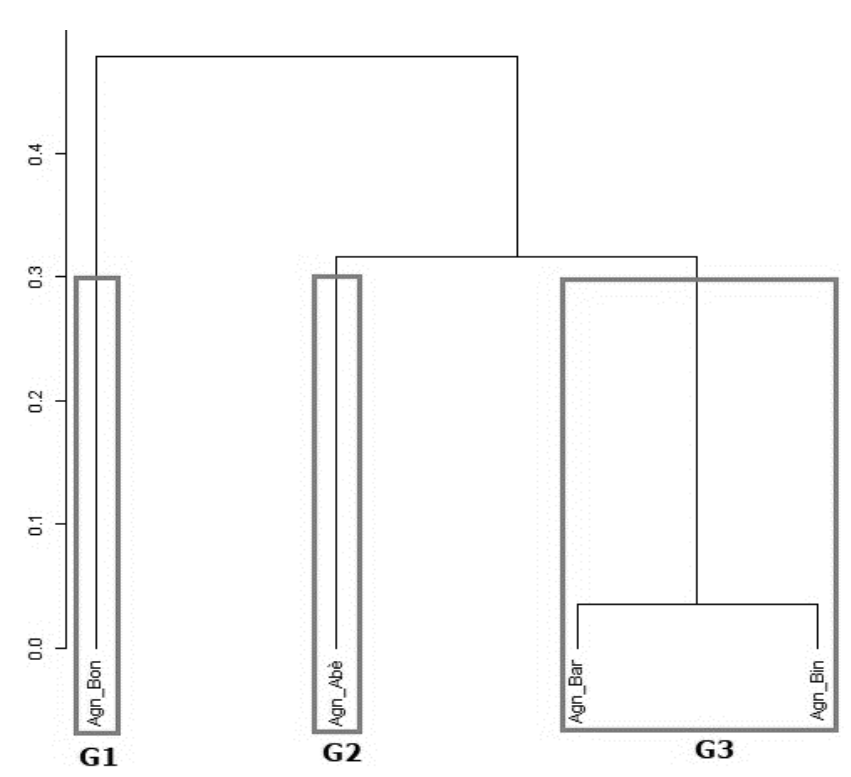

Figure 6. Hierarchical cluster of Agni tribes based on the mentioned wild edible plants: Agn-Abé: Agni-Abè, Agn-Bar: Agni-Barabo, Agn-Bin: Agni-Bini, Agn-Bon: Agni-Bona

\section{Discussion}

The evaluation of knowledge and practices on edible wild plants in the four tribes Agni showed that WEP of the tribes studied was diverse in terms of both the morphological types and the parts consumed. However, most of the plants listed in our study are known for the same uses by other peoples living in similar ecosystems both in Côte d'Ivoire and elsewhere in West Africa and many WEP lists were already established (see Ambé 2001; Bédiakon et al. 2007; Kouamé et al. 2008; Ouattara et al. 2016a and 2016b). Nevertheless, some plants such as Hibiscus congestiflorus Hochr., Laportea aestuans (L.) Chew, Securidaca longipedunculata Fresen., Synsepalum brevipes (Beker) T. D. Penn., Tiliacora dinklagei Engl., Trichilia monadelpha (Thonn.) J. J. de Wilde, Uvaria sofa were only mentioned in the study area and were absent of mentioned WEP lists. As it is well established by ethnobotanists, a plant use is, above all, a cultural expression (Dounias et al. 2000; Rakotosamimanana 2014).

Five parts of plants were eaten by these populations, however, the fruits were the most popular. This result is not an isolated case as worldwide, fruits were the most diverse and most consumed plant parts in terms of edible plants (Malela et al. 2016). This high consumption is closely linked to factors such as the distribution, availability over time as well as the organoleptic qualities of the concerned the fruits (Ambé 2001; Pardo-de-Santayana et al. 2007).

Comparative analysis between the four Agni tribes showed that the Agni-Barabo have the longest list of wild edible plants. On the other hand, concerning the lengths of the free lists, the Agni-Bini informants are in the lead. Various reasons could justify this observation. First, the vegetation is different from south to north of the study area. The Agni-Bona tribe is in the forest unlike the others (Agni-Abè, Agni-Barabo, and Agni-Bini) who are close to or located in the forest-savannah transition zone. The AgniBarabo tribe, located further north, has both savannah and some forest species by its position. The second reason could be linked to the degradation of the vegetation which also erodes the knowledge and know-how on WEPs. The natural habitats are to date greatly degraded in the AgniBona tribe and have given way to large plantations of cashew, rubber, and cocoa trees.

Our investigations showed a small proportion $(9.1 \%)$ of species well known and preferred by the populations. This result differs from what has been observed in neighboring populations in the Bondoukou department (Ouattara et al. 2016a), where almost $27 \%$ of spontaneous food plants are well known. This observation suggested a progressive abandonment of wild edible plants by the Agni tribes. Two major reasons could explain this loss of knowledge or this lack of interest in spontaneous edible plants. The first reason would be the taste of the consumed part. Some species such as Musanga cecropioides R.Br., Thaumatococcus daniellii (Benn.) Benth. etc.) which inflorescence for one or pulp for the other are widespread. However, their use as food is only slightly mentioned by the informants. Consumption of these parts arouses little enthusiasm because their taste is not appreciated.

The second reason is related to the availability of resources. For example, Pancovia sessiliflora Hutch. \& Dalziel and Pentadesma butyracea Sabine produce succulent and tasty fruits, but are limited to specific habitats (forest gallery, wetland, etc.), often far from habitation. Consequently, only people who have located productive feet benefit from it (Ambé 2001). The case of Ricinodendron heudelotii (Bail.) Heckel is special. In fact, the grains are prized by the populations of the southern half of Côte d'Ivoire as a condiment (Bédiakon et al. 2018). However, they are very little known, or even little used by people in the North (Ambé 2001). These seeds do not fit into the culinary habits of these communities.

Many practices fall gradually into disuse in some tribes. This is the case with the exploitation of palm wine, abandoned by the Agni-Barabo tribe, since it has mainly converted to the Muslim religion (Ouattara et al. 2016a). Women in the Agni-Bini villages, for the same reason, also abandoned the manufacture of shea butter as the rites for making it required the sacrifice of a goat each season. In short, the knowledge and practices linked to wild edible plants are gradually eroding.

Analysis of knowledge of spontaneous edible plants showed similarities and dissimilarities among the four tribes. The investigations revealed similarities between the Agni-Barabo and Agni-Bini tribes and a singularity of the knowledge and skills of the Agni-Abè and Agni-Bona. In fact, the Agni-Barabo tribes and the Agni-Bini use almost the same food plants. These similarities might be the result of a sharing of knowledge (Kouakou et al. 2020). The consumption of edible spontaneous plants among all ethnic groups results from the transmission of heritage, nevertheless, in some cases, food habits are acquired through cultural mixing (Batawila et al. 2007). Indeed, these two tribes have a common history since their 
migrations from present-day Ghana to Côte d'Ivoire in the $18^{\text {th }}$ century until their settlement on their current sites (Allou 2002). In addition, these two peoples share the same religion (Muslim) which facilitates inter-tribe marriages. They also share the same vegetation (semi-deciduous forest and wooded savannah) with a clear dominance of the savannah on the Agni-Barabo side. As we know, sharing knowledge makes it possible to enrich and popularize it and therefore to perpetuate it.

As for the Agni-Abè and Agni-Bona, their singularity concerning wild food plants could be explained by the fact that these two tribes are distant from each other and from the two other tribes (Agni-Barabo and Agni-Bini). In addition, they do not share the same types of vegetation. The food repertoire is linked to the culture of each people, even if nature offers a multitude of edible spontaneous plants, only those accepted culturally by the communities are consumed (Kouakou 2019).

In conclusion, this study assessed knowledge and practices on wild edible plants. From it emerges that knowledge and practices related to these plants are gradually degrading, especially among the Agni-Bona. It appears that $50 \%$ of the plants were little known as well as certain practices that were abandoned, because the associated rituals have become incompatible with the new religions. The mixing of knowledge is an encouraging note for the preservation of cultural knowledge and practices. This work, therefore, derives its importance in the urgent need to safeguard traditional knowledge and above all, as an element for the promotion and sustainable management of natural resources.

\section{ACKNOWLEDGEMENTS}

This work was carried out as part of the Ph.D. thesis work of the first author. Our thanks go to the heads of villages and people in the visited areas, who allowed us to work freely and who have always shown good cooperation. We also thank the managers of the Training and Research Unit of Natural Sciences Department (UFR SN) of the Nangui Abrogoua University for their logistical support. Finally, many thanks to our different guides and interpreter. The authors state that they have no competing interests.

\section{REFERENCES}

Allou. 2002. History of the peoples of Akan civilization. From the origin to 1874 . [Thesis]. University of Cocody, Côte-d'Ivoire

Ambé GA. 2001. Edible wild fruits in Guinean savannas of the Ivory Coast: state of the knowledge by local population, the Malinké. Biotechnol Agron Soc Environ. 5: 43-58

Batawila K, Akpavi S, Wala K, Kanda M, Vodouhe R, Akpagana K. 2007. Diversity and management of gathered vegetables in Togo. Afr J Food Agric Nutr Dev 7:1-16. www.ropkenya.org, [February 14, 2020]

Bédiakon BKD, Beugre GAM, Yao K, Ouattara D. 2018. Ethnobotanical survey on spontaneous food plants in Agboville department (Côte d'Ivoire). Intl J Sci Eng Res 9: 1843-1856
Borgatti PS. 1996. Anthropac 4.0. Natick, MA: Analytic Technologies. Elicitation technique for cultural domain analysis. Schensul J, Le compte M, Borgatti S, Nastasi B (eds). In the ethnographer's toolkit. 3: $115-151$

Dounias E, Rodrigues W, Petit C. 2000. Review of ethnobotanical literature for Central and West Africa. Bull Afr Ethnobot Netw 2: 5117

Dally T, Soko DF, Coulibaly S, Ouattara H, Meilé AKC. 2016. Contribution to the inventory of some spontaneous food plants used as ingredients of typical sauces: Case of Daloa, centra West of Côte d'Ivoire. Intl J Food Sci Nutr. 3: 160-164

Djaha AJB, Gnahoua GM. 2014. Contribution to the inventory and domestication of wild edible species of Côte-d'Ivoire: The case of Agboville and Oumé Departments. J Appl Biosci. 78 : 6620-6629.

Kouakou. 2019. Traditional uses of plants and availability of plant resources among the Koulango and Lobi peoples of the eastern periphery of the Comoé National Park. [Thesis], Nangui Abrogoua University, Côte d'Ivoire.

Kouakou YB, Malan DF, Kouassi GK, Diop AL, Bakayoko A. 2020. Availability of edible wild plants used by Koulango and Lobi populations on Eastern periphery of Comoé National Park, Côte d'Ivoire. Afr Sci. $16: 33-55$

Kouamé NMT, Gnahoua GM, Kouassi KE, Traore D. 2008. Spontaneous food plants of the Fromager Region (Western Center of Côte d'Ivoire): flora, habitats and organs consommés. Sci Nat 5: 61-70. DOI: $10.4314 /$ scinat.v5i1.42152

Kouassi AM, Kouamé KF, Koffi YB, et al. 2010. Analysis of climate variability and of its influences on seasonal rainfall regimes in West Africa: case of the N'zi (Bandama) watershed in Ivory Coast. Cybergeo Eur J Geogr 513 : 1-29

Lucena RFP, Araújo EL, Albuquerque UP. 2007. Does the Local Availability of Woody Caatinga Plants (Northeastern Brazil) Explain Their Use Value. Econ Bot. 61: 347-361

Lugo-Morin DR. 2020. Indigenous communities and their food systems: a contribution to the current debate. J Ethnic Foods 7: 1-10.

Malela KE, Miabangana SE, Petit J, N'zikou JM, Scher J. 2016. Ethnobotanical survey on the edible fruits of the spontaneous flora of the Republic of Congo. Intl J Pure Appl Biosci 4: 346-357

Ojelel S, Mucunguzi P, Katuura E, Kakudidi EK, Namaganda M, Kalema J. 2019. Wild edible plants used by communities in and around selected forest reserves of Teso-Karamoja region, Uganda. J Ethnobiol Ethnomed 15: 1-14

Orsay J-CK.1979. Application of the correspondence factorial analysis to the phytosociological study of the alpine stage of the central Pyrenees. Phytocoeconologia 5:125-188

Ouattara ND, Gaille E, Stauffer FW, Bakayoko A. 2016a. Floristic Diversity and ethnobotany of edible wild plants in the Department of Bondoukou (North-Eastern Côte d'Ivoire). J Appl Biosci 98:92849300

Ouattara D, Kouame D, Tiebre MS, Cisse A, N'guessan KE. 2016 b. Floristic diversity and uses of plants in Sudan area of Northwestern Côte d'Ivoire. J Anim Plant Sci 31: 4815-4830.

Pardo-de-Santayana M, Tardío J, Blanco E, Carvalho AM, Lastra JJ, Miguel ES, Ramón M. 2007. Traditional knowledge of wild edible plants used in the northwest of the Iberian Peninsula (Spain and Portugal): a comparative study. J Ethnobiol Ethnomed 3: 1-11

Quinlan M. 2005. Considerations for collecting free lists in the field: examples from ethnobotany. Field Methods 17: 1-16

Rakotosamimanana. 2014. Study of dietary practices and beliefs to understand malnutrition in Madagascar: interest of the introduction of Moringa oleifera leaves. Food and Nutrition. [Thesis]. University of Bourgogne, Dijon, France.

Schrauf RW, Sanchez J. 2008. Using free listing to identify, assess, and characterize age differences in shared cultural domains. J Gerontol Soc Sci 63: 385-933.

Sutrop U. 2001. List task and a cognitive salience index. Field Methods 13: 263-276.

Traore K. 2018. Forest cover in Côte d'Ivoire: a critical analysis of the forest management situation (closed forest, parks, and reserves). Intl J Soc Sci Humanit Invent 5: 4387-4397.

Yetein MH, Tenté BHA, Houessou LG. 2013. Ethnobotanical study of medicinal plants used for the treatment of malaria in plateau of Allada, Benin (West Africa). J Ethnopharmacol 146: 154-163. 